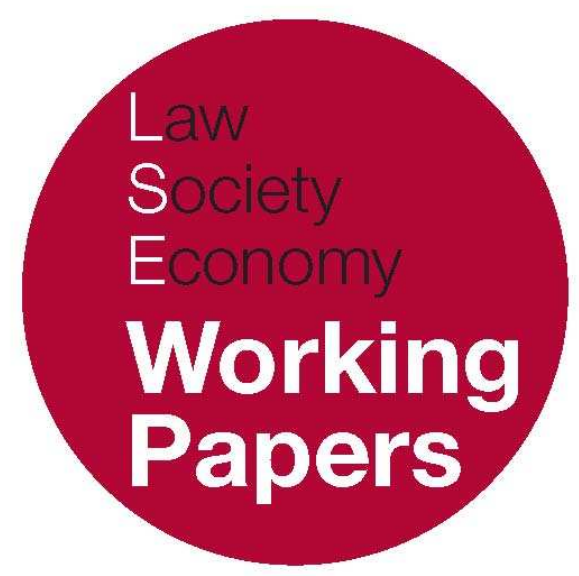

\title{
Judicial Review at the Margins: \\ Law, Power, and Prerogative
}

\author{
Thomas Poole
}

LSE Law, Society and Economy Working Papers 5/2010

London School of Economics and Political Science

Law Department

This paper can be downloaded without charge from LSE Law, Society and Economy Working Papers at: www.lse.ac.uk/collections/law/wps/wps.htm and the Social Sciences Research Network electronic library at: http://ssrn.com/abstract=1543144.

(C) Thomas Poole. Users may download and/or print one copy to facilitate their private study or for non-commercial research. Users may not engage in further distribution of this material or use it for any profit-making activities or any other form of commercial gain. 


\title{
Judicial Review at the Margins: Law, Power, and Prerogative
}

\author{
Thomas Poole*
}

\begin{abstract}
This essay on judicial review approaches its subject obliquely. It focuses on a particular site of constitutional abnormality: prerogative power. An analysis of the various iterations, historical and contemporary, between law and prerogative in its specific, rooted setting provides the basis for a more general account of the contemporary nature and role of judicial review, at a time when we appear to be entering a new 'age of prerogative' based on the politics of security and fear.
\end{abstract}

\section{INTRODUCTION}

Legal scholarship seems to thrive these days on the production of intense and apparently Manichaean oppositions. So, one of the contributors to this collection confidently divides the world between 'judicial review lovers' and 'judicial review haters'. ${ }^{1}$ Yet what is striking about the judicial review debate today is not so much the surface sturm und drang which, in as much as it does exist seems no more extensive and probably less intense than in many other disciplines, but rather its curiously dispassionate quality. This sanguine attitude fits the object of inquiry,

\footnotetext{
${ }^{*}$ Law Department, London School of Economics and Political Science. I would like to thank Adam Tomkins for the invitation to present a draft version of this paper at the symposium in Glasgow University, and all the participants at that symposium, but especially David Dyzenhaus and Janet McLean, for their comments.

1 A. Kavanagh, 'Constitutional Review, the Courts and Democratic Scepticism' (2009) 62 Current Legal Problems (forthcoming).
} 
grounded as it is in the measured language of Enlightenment Rationalism and rooted in a basic opposition of 'passions' to 'reason': the structuring and tempering, that is, of the dynamic and creative impulses of politics with the inherent reasonableness of settled law. ${ }^{2}$

The contemporary judicial review debate, uncommonly rich in certain regards, takes place within a narrow range. Scholarship is reduced temporally. Relentlessly focused on the present, it largely ignores - storybook Whig narratives aside - even its own origins and development. It is also reduced in range and ambition, in that it too readily assumes an easy umbilical connection between judicial review and individual rights. This double reduction may relate to background politics. We may not have witnessed an end to history in Fukuyama's sense, but the intense ideological conflicts that fuelled debates on judicial review a generation or so ago are now a distant memory. ${ }^{3}$ We all seem to be, in some sense or other, liberals now. It may also relate to the normalization of the practice of judicial review, which has established itself just about everywhere as a fixture of the political landscape. This process of entrenchment tends to undercut 'firstorder' debates about the legitimacy of judicial review, giving root-and-branch critiques an abstract, even antique, feel. ${ }^{4} \mathrm{~A}$ return to a lost Eden - or, depending on your point of view, that 'place of utter darkness, fitliest called Chaos'5 - where minimalist ('sporadic and peripheral') judicial review grubbed around in the political undergrowth is no longer a realistic option. ${ }^{6}$ Apart from anything else, it runs counter to the strong modern instinct to distrust legally unregulated exercises of political power. ${ }^{7}$

Judicial review has become normal or normalized, then, a basic accoutrement of the rule of law within a constitutional democracy. ${ }^{8}$ (This does not mean that it has become uncontroversial. ${ }^{9}$ Public law being a form of politics, it could hardly be so.) But a competing, anti-normalizing tendency is fast becoming a defining theme of $21^{\text {st }}$ century politics. Whether the immediate object is international terrorism, financial meltdown, health epidemics, or environmental disasters, governments

\footnotetext{
2 See, eg, S. Holmes, Passions and Constraint: On the Theory of Liberal Democracy (New York: Oxford University Press, 1995).

3 cf J.A.G. Griffith, 'The Political Constitution' (1979) 42 Modern Law Review 1; or better still Griffith, 'Why We Need a Revolution' (1969) 40 Political Quarterly, 383.

${ }^{4}$ Even Jeremy Waldron, the sceptics' current standard-bearer, has developed positions on ius gentium ('Foreign Law and the Modern Ius Gentium' (2005) 119 Harvard Law Review, 129) and the illegality of torture ('Torture and Positive Law' (2005) 105 Columbia Law Review, 1681) that sit uncomfortably with the anti-judicial review position with which his name is more closely associated. It is worth recalling that this position in any case (a) relates only to 'constitutional judicial review' and (b) only applies where there is a properly functioning democracy in operation. See, eg, J. Waldron, 'The Core of the Case against Judicial Review' (2006) 115 Yale Law Journal, 1346.

${ }^{5}$ Milton, Paradise Lost, Book I: The Argument.

${ }^{6} \mathrm{M}$. Tushnet, 'New Forms of Judicial Review and the Persistence of Rights- and Democracy-Based Worries' (2003) 38 Wake Forest Law Review, 813, 814.

${ }^{7}$ See, eg, J. Steyn, 'Guantanamo Bay: The Legal Black Hole' (2004) 53 ICLQ 1.

8 Compare, for instance, how Joseph Raz's thinking has changed on this subject from his 'The Rule of Law and its Virtue' (1979) 93 LQR 195 to 'The Politics of the Rule of Law' in Raz, Ethics in the Public Domain (Oxford: Oxford University Press, 1996).

${ }^{9}$ See, eg, D. Nicol, 'Law and Politics after the Human Rights Act' (2006) Public Law 722.
} 
everywhere talk about the need to agglomerate and streamline power to meet immediate or predicted crises. This phenomenon relates no doubt to our tendency to think in terms of risk. Giddens and other risk society theorists speak of 'manufactured risk': risks that result from processes of modernization, especially in the fields of science and technology, that create risk environments that have little or no historical reference and are as such largely unpredictable. ${ }^{10}$ There may also be a connection between the 'neurotic style' of contemporary politics and what Marquand calls the 'bland, almost narcotic populism'11 that drives it. Political commentators worry that Tocqueville's nightmare is poised to become reality: a society conditioned by individualism in which isolated citizens are easy to manipulate, their will softly bent and shaped by charismatic leaders, and where 'each nation is reduced to a flock of timid and industrious animals of which the government is the shepherd'. ${ }^{12}$ Government calls for exceptional powers and atypical legal frameworks are often defended on grounds of security, where 'security' embraces not only the traditional Hobbesian categories of defence against internal and external threat, ${ }^{13}$ but also protection against anti-social behaviour, ${ }^{14}$ perhaps even the nutritional health of citizens. ${ }^{15}$ However sceptical we are and however we might fear Tocqueville's dystopian vision of the decline of democracies, we cannot in all instances dismiss these claims out of hand as straightforward power-grabs by rent-seeking politicos.

Claims for exceptional powers have become part of the basic script of contemporary politics, and are problematic for judicial review. (Even more so in a climate where judicial review has become more prominent within public life, if only for the simple reason that more is now expected of it.) The claims usually relate to events that are likely to happen - or so we are told - in near future. As well as being about the selection of what current preferences will count as priorities, arguments about risk and about security are attempts to tame the future. ${ }^{16}$ They sketch (in Pascal's phrase) a 'geometry of hazard' to be played out in the domain of a necessarily unknowable future. They are, as such, structurally dismissive of the past. Past solutions tend to be presented as failed solutions, inadequate to meet novel demands. Judicial review, by contrast, looks to the past for sustenance and normative content. Its principles and its guiding sense of what

\footnotetext{
10 A. Giddens, 'Risk and Responsibility' (1999) 62 Modern Law Review 4. See also U. Beck, Risk Society: Towards a New Modernity (London: Sage, 1992).

${ }^{11}$ D. Marquand, 'Democracy in Britain' (2000) 71 Political Quarterly 268, 269

12 A. de Tocqueville, Democracy in America (London: Everyman, 1994), vol 2, book 4, ch 6. Compare John Gray's notion of 'agonistic liberalism': Enlightenment's Wake: Politics and Culture at the Close of the Modern Age (London: Routledge, 1996), ch 6.

${ }^{13}$ See, eg, I. Loader and N. Walker, Civilizing Security (Cambridge: Cambridge University Press, 2007).

${ }^{14}$ See, eg, P. Ramsay, 'The Responsible Subject as Citizen: Criminal Law, Democracy and the Welfare State' (2006) 69 Modern Law Review 29; 'Vulnerability, Sovereignty and Police Power in the ASBO' in M. Dubber and M. Valverde (eds), Police in the Liberal State (Stanford: Stanford University Press, 2008).

${ }^{15}$ See, eg, F. Furedi, Politics of Fear (London: Continuum, 2005).

${ }^{16}$ See, eg, F. Ewald, 'Insurance and Risk' in G. Burchell, C. Gordon and P. Miller (eds), The Foucault Effect: Studies in Governmentality (Chicago: University of Chicago Press, 1991). For analysis of risk in the context of public law, see E. Fisher, 'The Rise of the Risk Commonwealth and the Challenge for Administrative Law' (2003) Public Law, 455.
} 
counts as 'reasonable' are largely derived from the past, either by way of incremental development over time, ${ }^{17}$ or else through reflection on erroneous past behaviour ('social learning')..$^{18}$

The cognitive disjunction between a risk-framed and security-driven politics and the historically shaped and grounded matrix of law means that the latter tends to experience difficulty when confronted with situations presented as exceptional or abnormal. ${ }^{19}$ The cases decided in this 'red zone' where security politics and 'settled, standing law'20 collide often involve courts having to answer searching questions about the legitimacy of judicial review. The answers that they give to these questions will, in turn, have an impact (unpredictable no doubt) on the general standing of the court. In parallel situations in the past, usually in the context of war or serious civil unrest (eg martial law), the law's response has often been muted. ${ }^{21}$ But the response has been somewhat different in some recent terrorism cases, where courts have reaffirmed established values and the court's own role in policing them, often invoking in so doing the spirit of nationalism. The US Supreme Court in Hamdi v Rumsfeld applied overarching principles, derived from American history, to justify its ruling that an enemy combatant must be given an opportunity to contest their detention. ${ }^{22}$ And more bombast, Lord Hoffmann in the Belmarsh case ${ }^{23}$ ignored European and international legal sources and mounted a parochial defence of the legal control to emergency powers that was rooted in the specifics of British history. ${ }^{24}$

\section{THE PREROGATIVE AND THE BANALITY OF CONSTITUTIONAL ABNORMALITY}

This paper deliberately seeks out the constitutionally abnormal, presenting an analysis of judicial review on the margins. Its focus is the prerogative, a zone high in the constitutional stratosphere where passions tend to run high and the legal air thin. The prerogative (in its strict sense) refers to those powers left over from

\footnotetext{
17 The classic account in the contemporary era is that of Ronald Dworkin, whose theory of 'law as integrity' requires the development of legal and constitutional principles through moral/political reflection on past practice, especially legal practice: see, eg, Law's Empire (London: Fontana, 1987).

18 M. Tushnet, 'Defending Korematsu? Reflections on Civil Liberties in Wartime' (2003) Wisconsin Law Review, 273.

${ }^{19}$ A theme explored in T. Poole, 'Courts and Conditions of Uncertainty in 'Times of Crisis" (2008) Public Law 234.

${ }^{20} \mathrm{~J}$. Locke, Second Treatise on Government (1690), \137.

${ }^{21}$ See, eg, D. Dyzenhaus, The Constitution of Law: Legality in a Time of Emergency (Cambridge: Cambridge University Press, 2006).

22542 US (2004) 1, 25 (O'Connor J): 'during our most challenging and uncertain moments that our Nation's commitment to due process is most severely tested; and it is in those times that we must preserve our commitment at home to the principles for which we fight abroad.'

23 A v Secretary of State for the Home Department [2004] UKHL 56.

24 T. Poole, 'Harnessing the Power of the Past? Lord Hoffmann and the Belmarsh Detainees Case' (2005) 32 Journal of Law and Society 534.
} 
when the monarch was directly involved in government, powers that now include making treaties, declaring war, deploying the armed forces, regulating the civil service, and granting honours and pardons. Prerogative powers are exercised today by government ministers, or else by the monarch personally acting in almost all conceivable instances under direction from ministers. ${ }^{25}$ This basic definition shows that the prerogative has two faces - ordinary and extraordinary. The special and emergency powers it contains come mixed up with far more ordinary powers (eg over the civil service) and there is nothing formal or procedural separating one from the other. We might say, then, that the elements of constitutional abnormality within the prerogative exhibit a banal quality.

The choice of subject might seem eccentric. The rise of statute has led to prerogative's decline. This fact, as well as its regal association and origins 'time out of mind', combine to give the prerogative a musty feel. But the prerogative was central to British constitutional development. At the epicentre of the $17^{\text {th }}$ century crises out of which rose the modern constitutional settlement, it was also bound up with the creation of Britain's thalassocratic empire. ${ }^{26}$ The prerogative remains vital to the way in which the constitution is understood, acting as a kind of chiaroscuro against which more mainstream and better lit elements of the constitution are framed and their features brought out. The Whig narrative, which dominated political discourse from the Glorious Revolution, saw the prerogative squarely as the villain of the piece. This sentiment is well captured by John Allen in his $19^{\text {th }}$ century treatise on prerogative: 'Like the good and evil principles of the Persian magi, liberty and prerogative have been in perpetual conflict.' ${ }^{27}$ But even those working within the Whig tradition did not deny that the prerogative, although undoubtedly an aberrant power to be treated with suspicion, was fundamental to the maintenance of constitutional order. ${ }^{28}$ Locke, one of the founding fathers of the Whig tradition and more familiar than most with the way prerogative might be misused, rejected the civic republican call for the abolition of prerogative power in his chapter on king's prerogative in the Second Treatise. ${ }^{29}$

Even now, when the prerogative is no longer central to the grand narrative of British constitutional politics, traces of the older dialectic remain. The prerogative has a habit of resurfacing, with a whiff of sulphur, at moments of political tension.

\footnotetext{
25 There are also so-called 'personal prerogatives' which are exercised by the monarch herself. These include powers to appoint the Prime Minister, to dissolve Parliament, and to give Royal Assent to legislation. All these powers are strongly hedged by constitutional conventions. The Government has recently announced plans for a sweeping reform of prerogative power: see The Governance of Britain Green Paper (July 2007) and the Draft Constitutional Renewal Bill (March 2008).

${ }^{26}$ C. Schmitt, The Nomos of the Earth in the International Law of the Jus Publicum Europeaum (New York: Telos, 2006).

27 J. Allen, Inquiry into the Rise and Growth of the Royal Prerogative in England (London: Longman, 1849), 10. 28 Although not a Whig - or at least not straightforwardly so - this was also the position of David Hume. See his 'Of Passive Obedience' in David Hume: Essays Moral, Political, and Literary (Indianapolis: Liberty Fund, E.F. Miller (ed), 1987). On whether Hume was a Whig see, eg, J. Conniff, 'Hume on Political Parties: The Case for Hume as a Whig' (1978) 12 Eighteenth-Century Studies 150.

${ }^{29}$ n 20 above. See also, eg, C. Fatovic, 'Constitutionalism and Contingency: Locke's Theory of Prerogative' (2004) 25 History of Political Thought 276; P. Pasquino, 'Locke on Kings' Prerogative' (1988) 26 Political Theory 198.
} 
The war in Iraq is a recent case in point. The public were alarmed to (re)discover that government has no obligation to get Parliament's approval before taking the country to war - its prerogative powers are sufficient. (Not that it would have made much difference. The Prime Minister, Tony Blair, went to Parliament and got his vote.) Calls for reform followed. But, even if reform did occur and the kingly overtones of prerogative were removed, executive powers along similar lines would spring up in their place. These 'prerogative' powers (in the broad sense) would, as now, include emergency and reserve powers, and would still connect to personal (and charismatic) authority. It is this broader sense of the term that Judith Butler uses to describe the 'legal black hole' in Guantanamo Bay the handiwork of a 'resurgent prerogative'30 - and Ernst Fraenkel uses to explain Nazi Germany as a 'Prerogative State' in which ordinary law becomes eroded by 'arbitrary measures, in which the dominant officials exercise their discretionary prerogatives' in the interests of the Party. ${ }^{31}$

While prerogative in its strict (and strictly British) sense may well be in decline, then, the prerogative in the broader sense is anything but. It may be, in fact, that we are entering a new 'age of prerogative': certainly, the structure of prerogative matches in certain key ways the structure of risk and security politics. If this is right, then what follows here has even greater salience. The article starts by looking at the recent Bancoult case which, for all its idiosyncrasies, provides a telling case study of the contemporary state of the law on the prerogative.

\section{ANCIENT AND MODERN, REVISED: BANCOULT (NO. 2)}

Bancoult (No. 2) 32 concerned a challenge to the UK government's decision not to repatriate inhabitants of the Chagos Archipelago, a group of about 60 islands in the Indian Ocean. Originally a French possession (and leper colony), it was ceded to Britain after Napoleon's defeat in 1814. The Archipelago was turned into a separate territory (the British Indian Overseas Territory) in 1965 and depopulated in order to make room for a US military base on the Archipelago's chief island, Diego Garcia. All this was achieved through the exercise of prerogative powers first the BIOT Order 1965 and then the Immigration Ordinance 1971, which gave the newly establish BIOT Commissioner the authority (in colonial boilerplate) to 'make laws for the peace, order and good government of the territory'.

There had been a number of previous cases relating to the expulsion of the Chagossians in British courts. In Bancoult (No. 1), the 1971 Ordinance was held unlawful on the ground that a power to legislate for the 'peace, order and good

${ }^{30} \mathrm{~J}$. Butler, 'Indefinite Detention' in Butler, Precarious Life: The Powers of Mourning and Violence (London: Verso, 2006).

31 E. Fraenkel, The Dual State: A Contribution to the Theory of Dictatorship (New York: Oxford University Press, 1941), 3.

${ }^{32} \mathrm{R}$ (Bancoult) v Secretary of State for Foreign and Commonwealth Affairs [2008] UKHL 61. 
government' of BIOT, while broad, did not include a power to exile a people from their homelands. ${ }^{33}$ The people of the islands, as Laws LJ put it, 'are to be governed: not removed'. 34 The government issued a statement that it would not challenge the ruling. A new Immigration Ordinance was passed in 2000 permitting inhabitants to return to the outer islands of the Archipelago, but not to Diego Garcia. A feasibility study set up by the government after Bancoult (No. 1) reported in 2002 that while resettlement was possible (although expensive) in the short term, global warming would make the Archipelago uninhabitable in the longer term. The government decided in light of the report not to support resettlement. The US government also made known its concern that repopulating the Chagos Islands might compromise what it regarded as the unique security of Diego Garcia. New Orders were passed reinstating full immigration control. ${ }^{35}$ The claimants in Bancoult (No. 2) challenged these new arrangements. Their challenge was successful in the High Court and the Court of Appeal, where it was held that the Orders amounted to an abuse of power because, for reasons unconnected with their interests, the Orders negated the islanders' right to return to their homeland. ${ }^{36}$ The government appealed to the House of Lords.

The case must be set against a complicated back-story involving the law on the prerogative. ${ }^{37}$ It was established long ago that the courts could determine the existence and extent of a prerogative power: cases in the early $17^{\text {th }}$ century cases confirmed this. ${ }^{38}$ But it was also understood that courts could not question or review the manner in which a prerogative power had been exercised. ${ }^{39}$ This reticence relates to the prerogative's connection with the notion of 'the Crown', an unclear but structurally central concept within UK public law. ${ }^{40}$ Courts have in the

33 R (Bancoult) v Secretary of State for Foreign and Commonwealth Affairs [2001] QB 1067. For analysis see S. Palmer, "They Made a Dessert and Called it Peace": Banishment and the Royal Prerogative" (2001) Cambridge Law Journal, 234.

${ }^{34} \mathrm{R}$ (Bancoult), ibid at [57]. See also Chagos Islanders v Attorney General [2004] EWCA Civ 997, where the Court of Appeal held that this unlawful conduct did not give rise to liability in damages, affirming a settlement package agreed by the UK and Chagossian representatives in 1982.

${ }^{35}$ For commentary see S. Allan, 'International Law and the Resettlement of the (Outer) Chagos Islands' (2008) 8 Human Rights Law Review, 683.

$36 \mathrm{R}$ (Bancoult) v Secretary of State for Foreign and Commonwealth Affairs (No. 2) [2007] EWCA Civ 498. For analysis see R. Moules, 'Judicial Review of Prerogative Orders in Council: Recognising the Constitutional Reality of Executive Legislation' (2008) Cambridge Law Journal 12.

37 W.W. Lucas, 'Immunity of the Crown from Mandamus' (1909) 25 Law Ouarterly Review 290, 290: 'no branch of the law is so vague as that which relates to the legal status of the executive of the Crown and the relation it bears to the Judiciary'.

38 Probibitions del Roy (1607) 12 Co Rep 63; Case of Proclamations (1611) 12 Co. Rep. 74 at [76]: 'the King hath no prerogative, but that which the law of the land allows him.'

39 The courts also established the principle that if statutory powers exist that cover the same ground as a prerogative power, the government is in general not free to choose between them, but must act under the statute: Attorney-General v De Keyser's Royal Hotel Ltd [1920] AC 508. See also the dictum of Lord Diplock in $B B C \mathrm{v}$ Johns [1965] Ch. 32 at [79] that it was '350 years and a civil war too late for the Queen's courts to broaden the prerogative'.

40 The constitutional historian F.W. Maitland described the Crown as 'a convenient cover for ignorance' which 'saves us from asking difficult questions': in H.A.L. Fisher (ed), The Constitutional History of England (Cambridge: Cambridge University Press, 1980), 418. See also M. Loughlin, 'The State, the Crown and the Law' in M. Sunkin and S. Payne (eds), The Nature of the Crown (Oxford: Oxford University Press, 1999). 
past tended to act with special reserve when it came to reviewing legal acts done in the name of the Crown. This restrictive approach persisted until the mid-1980s when, in the GCHQ case, the House of Lords held that an instruction made under an Order in Council (the main form of prerogative legislation) could in principle be subject to judicial review. ${ }^{41}$ The case concerned Margaret Thatcher's sudden decision to deny trade union membership at Government Communications Headquarters (GCHQ), a military and signals intelligence centre. The 'law relating to judicial review has now reached a stage', one of the judges said, that 'if the subject matter in respect of which prerogative power is exercised is justiciable', the exercise of power will be subject to ordinary public law principles. ${ }^{42}$ But the modernizing aspects of the case were balanced by the survival of more traditional elements. The court went out of its way to identify areas of prerogative lawmaking activity that would in all likelihood never be justiciable. Lord Roskill detailed a list of 'excluded categories' - areas of activity supposedly immune from judicial review - that included powers 'relating to the making of treaties, the defence of the realm, the prerogative of mercy, the grant of honours, the dissolution of Parliament and the appointment of ministers'.43 The prerogative might now in principle be classified as a normal sub-statutory source of law for the purposes of judicial review; but in practice the courts still seemed to approach it with a caution bordering on outright deference. It is worth noting that although they won on the point of principle, the civil servants lost their case: their legitimate expectation of consultation was trumped by the government's assessment of the national security interests at stake. ${ }^{44}$

Bancoult (No. 2) centred on two issues. The first concerned the general question of the reviewability of prerogative legislation. This represented some unfinished business from the $\mathrm{GCHQ}$ case where it was held that acts done in the exercise of prerogative powers were reviewable, but left open the question to whether the same was true of the prerogative itself. The Law Lords in Bancoult (No. 2) unanimously ruled that judicial review applied. While it is true that prerogative Orders in Council are a type of primary legislation, they said, it does not follow that they share all the characteristics of Acts of Parliament, in particular their immunity from judicial review. 45 The prerogative lacks the representative character of an Act of Parliament, so there was 'no reason why prerogative legislation should not be subject to review on ordinary principles of legality, rationality and procedural impropriety in the same way as any other executive action. ${ }^{36}$

The second issue concerned the legality of this particular exercise of prerogative power, and on this question the House divided (3:2). The majority found the 2004 Orders were lawful, holding that the phrase 'peace, order and

\footnotetext{
${ }^{41}$ Council of Civil Service Unions v Minister for the Civil Service [1985] A.C. 374.

42 ibid at [387] (per Lord Scarman).

$43 \mathrm{ibid}$ at [418].

${ }^{44}$ See C. Walker, 'Review of the Prerogative: The Remaining Issues' (1987) Public Law, 62.

${ }^{45}$ See, eg, British Railwways Board v Pickin [1974] A.C. 765.

46 n 32 above at [35] (Lord Hoffmann).
} 
good government' relates to the governance of the entire Crown realm, and not just to those residing (or once residing) in BIOT. The phrase has always been treated, they said, 'as apt to confer plenary law-making authority.'47 Moreover, the case fell within a 'macro-political field' and was thus 'particularly within the competence of the executive'. ${ }^{48}$ Scrutiny of this sort of matter fell to Parliament and not the courts, since it raised a 'political, not judicial' question. ${ }^{49} \mathrm{~A}$ 'rule of abstinence' should be applied: however 'distasteful' the court might consider the provisions at issue, it should avoid interfering with "what is essentially a political judgment'.50 The majority also denied that the Chagossians had a legitimate expectation arising from the press statement after Bancoult (No. 1) that entitled them to resettlement.

The dissenting judges Lord Bingham and Lord Mance argued that the English courts have an inherent jurisdiction to delineate the scope of the prerogative power of colonial governance. ${ }^{51}$ They held that there was no prerogative power to make an order whose effect was to exile a population - 'the reciprocal duties of allegiance and protection...cannot ordinarily be discharged by removing and excluding the citizen from his homeland. 52 The right of abode is a fundamental 'and, in the informal sense in which that term is necessarily used in a United Kingdom context, constitutional' right that has been recognized since Magna Carta. ${ }^{53}$ No permissible distinction could be drawn between British citizens and those whose homes are in former colonial territories. Further, the term 'peace, order and good government' specifies a power 'intended to enable the proper governance of the territory, at least among other things for the benefit of the people inhabiting it. A constitution which exiles a territory's inhabitants is a contradiction in terms. ${ }^{54}$

The case is a controversial one, no doubt, and the Law Lords' decision has been met with consternation by most commentators..$^{55}$ But my concern here is not the merits of the case, but what it reveals about the current state of judicial review of the prerogative (and more generally about the relationship between law and power). For all its idiosyncrasies (and perhaps because of them), Bancoult may be

\footnotetext{
47 ibid at [50] (Lord Hoffmann).

$48 \mathrm{ibid}$ at [58] (Lord Hoffmann).

49 ibid at [109] (Lord Rodger).

50 ibid at [130] (Lord Carswell). Lord Carswell and Lord Rodger also ruled that the Colonial Laws Validity Act 1865 precluded judicial review, on the ground that Parliament in 1865 would simply not have contemplated the possibility of an Order in Council legislating for a colony as being open to challenge in an English court on principles of judicial review. This position relied heavily on a working paper by John Finnis: 'Common Law Constraints: Whose Common Good Counts?' March 2008) University of Oxford Law Faculty Legal Studies Research Paper Series, Working Paper No 10/2008.

${ }^{51}$ See Campbell v Hall (1774) 1 Cowp. 204.

$52 \mathrm{n} 32$ above at [70] (Lord Bingham).

53 \$29 of which provides that 'No freeman shall be...exiled...but by lawful judgment of his Peers, or by the Law of the Land'.

$54 \mathrm{n} 32$ above at [157] (Lord Mance).

55 See, eg, M. Elliott and A. Perreau-Saussine, 'Pyrrhic Public Law: Bancoult and the Sources, Status and Content of Common Law Limitations on Prerogative Power' (2009) Public Law, 697.
} 
seen as broadly representative of the case law and can thus provide a useful prism into this complex zone of constitutional politics.

Consider first the historical aspects of the case. Constitutional argument often involves consideration of the past, a fact to which British constitutional lawyers are particularly well attuned. Absent a constitutional text, the past becomes the main repository of constitutional principles, principles which need almost continual updating and refinement by means of a process of sifting through the historical material. ${ }^{56}$ The past weighs particularly heavily where prerogative is concerned, and judges in prerogative cases often talk about 'the clanking of mediaeval chains of the ghosts of the past'. ${ }^{57}$ But even by these standards Bancoult is replete with history. At least three historical strands are in play: (i) a Whig narrative according to which liberty and prerogative come fused in a continuous struggle for ascendancy; (ii) what might best be described as the English version of act of state doctrine, ${ }^{58}$ which is bound up in the old cases and commentaries with the prerogative and the notion of 'the Crown'; and (iii) a colonial narrative involving consideration of the relationship between the Imperial government and its overseas dominions. Each historical strand has a contemporary counterpoint. The Whig narrative connects with the standard account of the rise of judicial review since the 1960s. The act of state narrative meshes with today's risk and security politics. The colonial narrative, played out in a post-colonial space, requires courts to consider the extent to which it ought to feel bound by old colonialist legal positions.

The court divided in the face of these encircling historico-legal questions. The minority embraced the Whig position, denied the act of state argument, and felt free (although they did not express things in these terms) to radically rework a neo-imperial provision in a way that avoided injustice. ${ }^{59}$ The majority distrusted the attempt to foist a grand Whiggish narrative on the case. Taking a more historically-inflected view of the 'peace, order and good government' clause at the centre of the litigation, they preferred to navigate a line consistent with the act of state principle. This position was more conservative in its approach to the prerogative specifically, but also in its understanding of the court's constitutional role.

Secrecy and the politics of security provide another of the case's main themes. The policy shift at the centre of the case was justified partly on national security grounds: the Minister had said in Parliament that 'developments in the international security climate' since Bancoult (No. 1) were central to the

\footnotetext{
56 See J.W.F. Allison, The English Historical Constitution (Cambridge: Cambridge University Press, 2007).

57 L Atkin in United Australia Ltd v Barclays Bank Ltd [1941] AC 1 at [29]; L Roskill in Council of Civil Service Unions v Minister for the Civil Service [1985] AC 374 at [417]; L Hooper in R (Bancoult) v Secretary of State for Foreign and Commonwealth Affairs [2001] 2 W.L.R. 1219 at [158].

58 W. Harrison Moore, Act of State in English Law (New York: E.P. Dutton, 1906).

${ }^{59}$ For a discussion of this perspective in the context of indigenous rights see P.G. McHugh, 'A History of the Modern Jurisprudence of Aboriginal Rights - Some Observations on the Journey So Far' in D. Dyzenhaus, M. Hunt, and G. Huscroft (eds), A Simple Common Lawyer: Essays in Honour of Michael Taggart (Oxford: Hart Publishing, 2009).
} 
government's change of heart. ${ }^{60}$ The volte face also owed something to US security concerns. Remote though it is, Diego Garcia is not peripheral within the post9/11 security world. Persistent rumours circulate about its use for 'extraordinary rendition' flights. Lord Hoffmann referred to these allegations when he said in Bancoult (No. 2) that 'Diego Garcia or a ship in the waters around it have been used as a prison in which suspects have been tortured'. ${ }^{61}$ The US denies these allegations, but they are far from implausible. And where secrecy reigns, we naturally suspect the presence of unsavoury things.

Bancoult sits, then, at the confluence of two histories of shady state secrets or half secrets. One relates to the shabby dealings of the post-imperial (and Cold War) past; the other to contemporary security obsessions and the 'war on terrorism' (or whatever we are now to call it). The presence of the prerogative here is apt,for that source of power has long been associated with constitutional exceptionalism and the mysteries of state - a theme explored in the next section. Bancoult shows how prerogative is often found at the furthest reaches of constitutional discourse. ${ }^{62}$ In a constitution devoid of clear lines, it is perhaps the closest thing we have to Agamben's idea of a defining threshold or limit concept, a zone of indistinction between outside and inside, exclusion and inclusion where sovereign power and bare life threaten to elude the domain of politico-juridical representation. ${ }^{63}$ Agamben's thesis is that 'the fundamental activity of sovereign power is the production of bare life as originary political element and as the threshold of articulation between nature and culture, zoe and bios.' ${ }^{64}$ It is hard to resists the parallels between this thesis and the Chagos Islands litigation. On this reading, the Chagossians adopt the role of homo sacer, the liminal figure in Roman law of the man who can be killed but not murdered whom Agamben takes to be emblematic of modern legal order. The sovereign treated them as bodies rather than subjects. ${ }^{65}$ (Worse still, by seeking to deny their existence in the late 1960s, it tried to make them ghosts.) And the question at the heart of the litigation becomes whether the government's exercise of sovereign power could be made to fall within the domain of law (and if so to what effect). But there is an additional twist. Since all parties agreed that the right of repatriation, even if granted, could not be vindicated, the case involved not legal rights in the sense that craggy, remediesfocused common lawyers like Dicey might have recognized, but what might best be called 'pseudo-rights'.

\footnotetext{
${ }^{60} \mathrm{n} 32$ above at [27].

$61 \mathrm{ibid}$ at [35].

${ }^{62}$ See further A. Tomkins, 'Magna Carta, Crown and Colonies' (2001) Public Law, 571.

63 G. Agamben, Homo Sacer: Sovereign Power and Bare Life, D. Heller-Rozen (trans) (Stanford: Stanford University Press, 1998).

64 ibid, 181.

${ }^{65}$ See also G. Agamben, The Open: Man and Animal, K. Attell (trans) (Stanford: Stanford University Press, 2004); R. Esposito, Bios: Biopolitics and Philosophy, T. Campbell (trans) (Minneapolis: Minnesota University Press, 2008).
} 


\section{THE PREROGATIVE AND ARCANA IMPERII}

Bancoult is an extraordinary case. At once on the margins of juridical discourse and yet also generating threshold questions of fundamental reach, it combines elements of all-but-forgotten history with über-contemporary considerations of realpolitik. The case is about everything, since it asks what government can do to us in the name of security; but it is also about nothing since the option of awarding a real remedy was always foreclosed. It contains shady powers, half-hidden diplomatic missives, elusive justifications - even ghosts (of a sort). And it split the court down the middle. But elements that might seem specific to Bancoult are in fact recurring themes within the history of the prerogative and its iterations with law. Or at least this is the proposition that is tested in this section.

One standard image of prerogative, influenced by Locke, is of a direct and unconstrained power, justified usually by the exigencies of circumstance, to be exercised in the public good. This vision of prerogative as untrammelled power is reflected in the words Shakespeare puts in Macbeth's mouth when arranging the murder of Banquo: 'though I could / With barefaced power sweep him from my sight / And bid my will avouch it' 66 But this idea of 'barefaced power', justified by princely will alone, is misleading. For in fact prerogative is a power that is historically modulated, legally bounded, and anything but an uncomplicated expression of 'honest' brute force.

As Bancoult suggests, in the prerogative we approach a realm of law inhabited by fictions, spectres, and ghosts. It is striking how often the language of the supernatural appears in the cases and commentaries on the prerogative. ${ }^{67}$ It is Blackstone, rather than Locke, who provides the surer guide on this particular subterranean journey. Blackstone described the prerogative as something 'singular and eccentrical':

a topic that in some former ages was ranked with among the arcane imperii [secrets of state]; and like the mysteries of the bona dea $^{68}$ was not suffered to be pried into by any but such as were initiated in its service; because, perhaps, the exertion of one, like the solemnities of the other would not bear inspection of a rational and sober inquiry. ${ }^{69}$

Blackstone, whose interests lay elsewhere, chose not to probe the mythical connotations of prerogative. But one way of doing so would be to focus on prerogative's theological associations. Carl Schmitt argued that all the key concepts

\footnotetext{
66 Shakespeare, Macbeth, Act III, Scene I.

${ }^{67}$ See, eg, J. Pryor, 'Conjuring Spectres: Locating the Constitution of Britain in its Post-Imperial Moment' in Pryor, Constitutions: Writing Nations, Reading Differences (Abingdon: Birkbeck Law Press, 2008).

68 The 'good goddess': refers to the Roman goddess of fertility attended to by the Vestal Virgins.

69 W. Blackstone, Commentaries on the Laws of England, Vol. I (1765, Chicago: University of Chicago Press, S.N. Katz ed., 1979), ch. 7.
} 
of modern political theory are secularized theological concepts. ${ }^{70}$ By this he meant not only are our public law concepts derived historically from theological ideas, particularly those associated with the Roman Church, but also that their conceptual logic still mirrors that of the religious concepts from which they are derived..$^{71}$ The theological analogy to the prerogative is the miracle. Both are at odds with the existing order (whether material or normative) but by definition transcend it. (They are both also, in a sense, emanations of divine authority which through their exercise also indicate the existence of the divine.) Both must therefore elude full rational treatment. This line of argument, while suggestive, fails to grasp the two-faced character of prerogative which is, as we have seen, simultaneously mundane and extraordinary. It also depends on the existence of a well-defined boundary between prerogative and ordinary law, norm and exception, of the type that the common law constitution denies. ${ }^{72}$

That is not to say that there is no trace of the miraculous in conceptions of the prerogative. Even Blackstone's account, for all that it drips with urbane irony, does not deny this. Indeed, the very etymology and meaning of the word 'prerogative' hints at a relationship with the non-material. The Latin praerogativia referred not only to the tribe that voted first in the Comitia, and by extension a prior preference, privilege or claim. It also meant a token or omen. The English derivate prerogative took on the more particular meaning: a special right or privilege possessed by an individual or groups, or an inherent advantage or privilege. But the otherworldly element to the idea did not altogether disappear, at least in the context we are discussing, where it was bound up with the idea of majesty. The king's prerogative originally denoted those rights and privileges due to the monarch by virtue of his position as feudal overlord. This bundle of original kingly rights related almost entirely to land holding. "The process of seizing land and granting livery of it was a profound expression of lordship, and the exercise of prerogative lordship was an equally profound expression of kingship. ${ }^{73}$ These traditional rights were presented in a text called Prerogativa Regis, a statute (if such it was - almost too perfectly, contemporaries were uncertain as to whether it was a statute or not $)^{74}$ passed probably in the reign of Edward I or Edward II. ${ }^{75}$ These feudal rights, although increasingly anachronistic, were exploited more systematically during the years of the 'New Monarchy' (from the restoration of

\footnotetext{
70 C. Schmitt, Political Theology: Four Chapters on the Concept of Sovereignty, G. Schwab (trans) (Chicago: University of Chicago Press, 1985); Schmitt, Römischer Katholizismus und Politische Form (Hellerau: Jakob Hegner, 1923).

71 See also G. Buijs, 'Que les Latins appellant maiestatem: An Exploration into the Theological Background of the Concept of Sovereignty' in N. Walker (ed), Sovereignty in Transition (Oxford: Hart, 2003).

72 See T. Poole, 'Constitutional Exceptionalism and Common Law' (2009) 7 International Journal of Constitutional Law 247.

${ }^{73}$ M. McGlynn, The Royal Prerogative and the Learning of the Inns of Court (Cambridge: Cambridge University Press, 2003), 248.

74 ibid, 8.

75 cf E.F. Henderson, "The Date of "Prerogativa Regis" (1890) 5 English Historical Review, 753 arguing for an earlier date in the reign of Henry III.
} 
Edward IV to the death of Henry VIII) not only to obtain money for the Crown, a necessary obsession of the kings of this period, but also to keep tabs on the nobility. The prerogative was, then, 'a means of inculcating a healthy fear of royal power', ${ }^{76}$ and played an important role in the move from the early Lancastrian idea of the king as first among equals to the Tudor conception of the king as a lonely being elevated above even the greatest of his Lords. ${ }^{77}$ It was only later, with the reign of the early Stuart kings, that the prerogative took on its now more familiar (Lockean) colouring as an exceptional and emergency power. ${ }^{78}$

It would be a mistake to see monarchy as simply a system of rule. As Paul Kléber Monod observes, 'monarchy was not just a system of worldly dominance; it was a reflection of God, and an ideal mirror of human identity. It was a link between the sacred and the self. ${ }^{3} 79$ We see this idea reflected in the intricate notion of the kings' two bodies, developed by medieval jurists to demonstrate that the monarch possesses two personalities or capacities, the natural and the political. ${ }^{80}$ The personal and political were intricately connected, and wrapped up within a sacral model of authority. 'The King has been invested by law and religion with a character at once despotic and divine. His office has been deemed sacred as a delegation from Heaven, and the sacredness of his office has been communicated to his person. ${ }^{81}$ The mystical head of the political body - the crown - could be thought of as being contained within the physical body of the king, an invisible element known as his dignitas. While the king's physical body could expire, the dignitas element was immortal. ${ }^{82} \mathrm{Or}$, as Coke put it more sardonically: 'The King in genere dieth not; but, no question, in individuo, he dieth'. This personal conception of authority endured well into the early modern era. In early $17^{\text {th }}$ century England, the judges were called upon in the Case of the Post-Nati ${ }^{83}$ to decide whether a Scot born in Edinburgh after James's accession to the English throne was entitled to inherit land in England and enjoy the benefit of English law. The judges decided that he could, and in so doing drew upon old theories of authority. ${ }^{84}$ Allegiance, they ruled, was owed not just to the monarch's crown, that is the corporate body or state, but also to his or her natural person as well. 85

The prerogative, as a power that inhered singularly in the king qua king, represented a direct emanation of royal authority and so took on a strong sacral

\footnotetext{
76 n 73 above, 248 .

77 D. Starkey, The English Court: From the Wars of the Roses to the Civil War (London: Longman, 1987), 3.

78 For an analysis of the economics (as well as politics) behind this move, see M.J. Braddick, State Formation in Early Modern England c.1550-1700 (Cambridge: Cambridge University Press, 2000).

79 The Power of Kings: Monarchy and Religion in Europe, 1589-1715 (New Haven: Yale University Press, 1999),

80 E.H. Kantorowicz, The King's Two Bodies: a Study of Mediaeval Political Theology (Princeton: Princeton University Press, 1957).

81 n 27 above, 24 .

82 n 79 above, 41 .

83 Also known as Calvin's Case (1608).

84 C. Russell, The Causes of the English Civil War (Oxford: Oxford University Press, 1990), 157-8.

85 A. Allan Orr, Treason and the State: Law, Politics and Ideology in the English Civil War (Cambridge: Cambridge University Press, 2002), 50.
} 
hue, becoming 'an incongruous mixture of real and imaginary qualities...which has been called the union of his natural with his mystic or politic capacity'. ${ }^{86}$ But there is an equally important dimension to the prerogative, related to ideas of majesty and the personal conception of the state, which reflects the 'deep structure' of medieval and early modern life. The notion of service was a central organizing concept at the time, 'the dominant condition that tied people to each other and the framework that structured the ways in which they lived such relationships' ${ }^{87}$ What we would see today as employment relationships governed by contract, for instance, would at the time have been understood in terms of occupational service. Allied notions of mastery and service pervaded the political sphere, where service was fundamental to contemporary thinking about political relationships. A trope of $16^{\text {th }}$ century 'mirror for princes' and household conduct-books was the idea of the 'Golden Chain', informed by rank but not by social status or class, an interconnecting and multiply re-enforcing network of service relationships that generated bonds of loyalty and reciprocal obligation. The bond between 'master' and 'servant' in this sphere was at once political and intensely personal (or 'as though' personal), carrying with it obligations of love, affection, and affective connection. As Lear says to Kent, 'Thou serv'st me, and I'll love thee'. ${ }^{88}$ The word 'love' stands here for, or intensifies, attitudes of obligation and expectations of reciprocal duty: 'attestations of political love [shift] the valences of the personal towards the realities of public service. ${ }^{39}$ These networks of service relationships generated a structure (or were intended to) in which 'Authority was besieged with obligations of love and care'. ${ }^{90}$ Since to exist outside service relationships altogether would amount to social non-existence, freedom could only be found, in the ideology of the time, within the context of such affective bonds. 'Service', as the Tudor Book of Common Prayer had it, 'is perfect freedom'.

The prerogative took shape against this cultural background. Its two faces, at once ordinary and special, reflect different aspects of the king's mastery. The prerogative power over the civil service, for instance, at issue in the $G C H Q$ case, reflects a master's prerogative to keep his servants at his beck and call. Prerogatives of war, diplomacy, and the preservation of the peace, ${ }^{11}$ relate to the king's need to secure mastery over all those who threaten his state. The language of service is scatted across the old texts on prerogative. (It even appears in the passage from Blackstone's Commentaries quoted earlier.) We can see the operative force of this rhetoric in the great case dealing with the prerogative in the imperial setting, Campbell v Hall. ${ }^{92}$ Lord Mansfield sets out in his judgment the

\footnotetext{
${ }^{86}$ n 27 above, 22.

${ }^{87}$ D. Schalkwyk, Shakespeare, Love and Service (Cambridge: Cambridge University Press, 2008), 19.

${ }^{88}$ Shakespeare, King Lear, Act I, Scene 4.

${ }^{89} \mathrm{n} 87$ above, 178.

${ }^{90} \mathrm{~K}$. Wrightson, 'The Politics of the Parish in Early Modern England' in P. Griffiths, A. Fox, and S. Hindle (eds), The Experience of Authority in Early Modern England (London: Macmillan, 1996), 11.

${ }^{91}$ See, eg, R v Secretary of State for the Home Department, exp Northumbria Police Authority [1987] EWCA Civ 5; [1989] Q.B. 26.

92 [1774] Cowp. 208.
} 
proclamation ('Great Seal') through which the Crown took possession of Grenada. The last sentence of the proclamation speaks of the 'public peace, welfare, and good government' of our colonies - almost identical to the phrase at issue in Bancoult. But the beginning of the text is more interesting for present purposes. It reads:

Whereas it will greatly contribute to the speedy settling of our said governments, of which the island of Grenada is one, that our loving subjects should be informed of our paternal care for the security of the liberties and properties of those who are and shall become inhabitants thereof...[The proclamation continues by calling for the establishment of a general assembly.]

The prerogative fits perfectly the destructive/creative dynamics of the imperial enterprise, the taking of new territory in particular. Not only is peace and war prerogative's natural habitat, or one of them. The prerogative is also an instrument of lawful authority that carries with it more than a hint of the exceptional, bound up as it is with ideas of majesty and command. The common law and the other accoutrements of normal, civilized justice might - should - come next. But note in particular the phrases 'our loving subjects' and 'our paternal care' in the proclamation. What they indicate is the instigation of a structure or relationship of service between the King/Crown and the inhabitants of Grenada. The proclamation, in other words, is a performative utterance through which a bond of loyalty and affection is to be created. We, with our post-colonial bent and recognizing the imbalances of forces in play, might be tempted to read this situation entirely cynically. But the utterance was one with real intent and carried real consequences, as Campbell v Hall itself illustrates. Lord Mansfield, despite finding the $4 \frac{1}{2} \%$ duty imposed in Grenada fair and equitable, ruled it unlawful since, where a colony has a representative assembly, taxation could not be imposed without its consent or by Act of Parliament. The King thus has no floating colonial powers by virtue of his prerogative. His colonial prerogative was limited not only by a deeply entrenched ideology and social norms relating to service, but also by the demands of ordinary law which reflected that ideology and served to embed those norms.

Far from being an expression of 'barefaced power', then, the historical prerogative was imbricated within a dense socio-political (and legal) web and background ideology of service. One implication of this was that the king was bound in exercising his prerogative power, as he was in all his actions, by bonds of loyalty and affection. (Or as James I put it, the 'reciprock and mutuall duetie betwixt a free King and his naturall Subjects'. ${ }^{93}$ ) Even a tyrant like Macbeth was forced to play this game. In the passage already referred to, Macbeth could not

93 This is the subtitle of James's The Trew Law of Free Monarchies [1598], written when he was James VI of Scotland. 
openly sweep Banquo from his sight, but was forced into 'Masking the business from the common eye' because 'certain friends that are both his and mine / Whose loves I may not drop, but wail his fall / Who I myself struck down'. (He chose the extra-legal path of political assassination instead.) In early modern England, the king himself was seen (and saw himself) as playing the servant's role in his relationship with God. The divine sanction to rule claimed by kings rested on serving God well, ${ }^{94}$ which meant dealing with their subjects in a manner compatible with law divine, natural, and human: 'a king that governes not by his lawe, can neither be accountable to God for his administration, nor have a happy and established raigne. ${ }^{95}$ And, even though the existence of a coercive secular jurisdiction over the king would have been almost universally denied in this period, the late medieval and early modern state was a 'law-saturated polity'. ${ }^{96}$ There was a deep commitment to law, and the polity was understood to be constructed through law. Any suggestion that the prince and his prerogative were altogether outside the domain of law would have been met with profound hostility. Of such claims were tyrants made. The prince might legitimately claim absolute power. But absolute power was not absolute, at least not if it meant a supreme, arbitrary authority capable of obliterating the rights of subjects. Bracton, writing on the fringes of a wider European debate, granted that the king was legibus solutus (not bound by the laws). But what he probably meant was not that the king was free to dispense from the law, but that he could legislate but was not free from legal norms. ${ }^{97}$

The prerogative, which so often provided the legal anvil on which these arguments were hammered out, had little in common with the 'legal black hole' of the modern imagination. Even the great $17^{\text {th }}$ century battles over prerogative occurred within or were about the framework of legal and constitutional rule, an internal struggle over what existing law actually entailed as opposed to a clash between implacably opposed ideologies. But what this state of affairs - being unbound by law, and yet bound - meant in practice was a separate question. The courts were called to adjudicate upon it at various stages in the worsening crisis. Hopes generated by Coke's assertions about the jurisdictional superiority of the common law over prerogative ${ }^{98}$ were not met. The 'power of Courts are a delicate subject, coming very near to the mystery part of prerogative', Moore writes in his

94 Rémi Brague, The Law of God: the Philosophical History of an Idea (Chicago: University of Chicago Press, 2007), 221 observes that God was thought (at least in the tradition following Thomas Aquinas) to submit himself, in a certain manner, to a law. The idea of eternal law makes it possible to think that there is a law common to God and his creatures.

95 James I, Workes (1616 edn), 203. See further G. Burgess, Absolute Monarchy and the Stuart Constitution (New Haven: Yale University Press, 1996), ch 2.

96 A. Cromartie, The Constitutionalist Revolution: An Essay on the History of England, 1450-1642 (Cambridge: Cambridge University Press, 2006), 180.

97 For a discussion of legibus solutus in the context of theories of the 'absolute' prince, see K. Pennington, The Prince and the Law, 1200-1600: Sovereignty and Rights in the Western Legal Tradition (Berkeley: University of California Press, 1993), 21.

98 n 38 above. 
treatise Act of State in English Law, ${ }^{99}$ and $17^{\text {th }}$ century judges did little to make it any less mysterious. The judges fudged the issue in the Five Knights Case (1627) - We are too wise, nay, we are too foolish in undertaking to examine matters of State to which we are not born.' ${ }^{100}$ This pleased no-one, least of all the House of Commons which passed the Petition of Right at the first opportunity. ${ }^{101}$ In the Case of Ship Money (1637), the judges accepted (by a majority of 7 to 5) the king's view that Ship Money was not a tax but a service owed to the king in emergency to enable him to carry out his duty to defend the realm. The laws know 'no kingyoking policy', one of them said. ${ }^{102}$

We are back where we started, with a court split down the middle working out liminal questions of law and power, although, to paraphrase Marx, what was first tragedy (in Ship Money) is now played out as something more like farce (Bancoult). When push comes to shove, it might seem, 'high' prerogative cases, whether in the $17^{\text {th }}$ century or today, tend to go the government's way. But, for all that, the cases do not show prerogative as a straightforward expression of barefaced power and princely will. However wrong the result might have seemed to contemporaries, both Ship Money and Bancoult involved exercises of 'high' prerogative being openly questioned before an independent (or at least not wholly subordinate) tribunal where the outcome would not have been certain. Far from being an unadulterated expression of princely will, the prerogative operated within an all-encompassing network of service relationships, generating bonds of allegiance that reached even to God and that carried with them notions of legal restraint. Far from being 'barefaced', the exercise of prerogative power is often in practice occluded and wrapped in half-truths. Or, as Macbeth puts it, 'Masking the business from the common eye, / For sundry weighty reasons. ${ }^{103}$ The court is often asked to accept, as it were on trust, something that is manifestly less than total truth. The question it must ask itself in turn is how much and how hard it wants to push against the reality that is presented to it in the name of the rule of law.

\section{THE PREROGATIVE AND THE LAW}

We have seen the progression of prerogative from a power vested in the king qua feudal overlord to the perquisite of an exalted king bound up in a web of service

\footnotetext{
${ }^{99}$ W. Harrison Moore, Act of State in English Law (London: John Murray, 1906), 11. 100 ibid, 13.

101 J.A. Guy, 'The Origins of the Petition of Right Reconsidered' (1982) 25 Historical Journal, 289.

102 'The King's Case laid before the Judges, with the Answer' (Feb 7, 1637, Rushworth, ii. 355). The judge in question was Finch. See also Crawley: 'You cannot have a king without these royal rights'.

103 Compare John Donne, Meditation X, on illness: 'The disease hath established a kingdom, an empire in me, and will have certain arcana imperii, secrets of state, by which it will proceed and not be bound to declare them.' See further M.W. Price, 'Recovering Donne's Critique of the 'Arcana Imperii in the Problems" (2004) 101 Studies in Philology, 332.
} 
relations. The final section returns the inquiry to the present. It reflects on the contemporary conception of prerogative as a simple set of executive powers to be understood against a background conception of 'horizontal' political relations between democratic equals.

Let us start by interrogating the post-GCHQ claim that prerogative powers are amenable to judicial review in the normal way. The modern Whig would see GCHQ and its progeny as having normalised one of the last areas of aberrant legality, enabling courts to shine the light of reason into previously obscure corners of power. David Dyzenhaus captures this position particularly well in his recent work on martial law. While the $20^{\text {th }}$ century saw the development of a state governed effectively by the rule of law, he says, the 'one exception was national security and other powers considered to be exercised by prerogative. But both the prerogative and national security are now recognised to be amenable to the controls of the rule of law, including judicial review.'104

It is certainly true that, in the modest profusion of prerogative cases since GCHQ, almost none have been held to be non-justiciable. ${ }^{105}$ The rolling back of Lord Roskill's 'excluded categories' of powers supposedly immune from judicial scrutiny provides a textbook illustration, the Whig might be tempted to say, of the teleology of the common law, its antipathy to hidden power and its aspiration to liberty. 106 Two and a half decades on from GCHQ, most of Lord Roskill's catalogue is now in principle open to review. But it is not just that the range of reviewable prerogative powers has increased. In some areas, judicial review now penetrates deeper. ${ }^{107}$ The best example of this development relates to the prerogative of mercy. ${ }^{108}$ Before $G C H Q$, the courts would simply not have examined a mercy decision: 'It is outside the competence of the courts to call it into question: Nor would they wish to do so.'109 'Mercy is not the subject of legal rights. It begins where legal rights end.'110 In Bentley, decided after $G C H Q$, the sister of a man executed for murder successfully challenged the Home Secretary's

\footnotetext{
104 D. Dyzenhaus, 'The Puzzle of Martial Law' (2009) 59 University of Toronto Law Journal 41.

105 One possible exception is R (Gentle) v The Prime Minister [2006] UKHL 20, where the House of Lords rejected a claim brought by relatives of servicemen and women killed in Iraq that the right to life under Article 2 ECHR required the government to set up an inquiry into the lawfulness of the decision to go to war in Iraq. Lord Bingham referred (at [8]) to 'the restraint traditionally shown by the courts in ruling on what has been called high policy - peace and war, the making of treaties, the conduct of foreign relations'.

106 See, eg, T.R.S. Allan, Constitutional Justice: A Liberal Conception of the Rule of Law (Oxford: Oxford University Press, 2003).

107 R v Secretary of State for the Home Department, ex p Fire Brigades Union [1995] UKHL 3; [1195] 2 A.C. 513 involved a successful challenge to the government's attempt to invoke prerogative powers to instigate a compensation scheme that differed in key respects to one that had been authorized by an Act of Parliament. The case is probably best understood, however, in traditional terms; that is, as an elaboration of the principle in De Keyser case (n 39 above) protecting the authority of Acts of Parliament against exercises of the prerogative.

108 See also the review of the prerogative power to issue passports: eg, $\mathrm{R} v$ Secretary of State for Foreign and Commonwealth Affairs, exp Everett [1988] EWCA Civ 7; [1989] Q.B. 811. Although the familiar disjunction between principle and result, rhetoric and reality occurs in this case - the claimant lost. See also Mohit v Director of Public Prosecutions of Mauritius [2006] UKPC 20 (successful challenge to prosecution policy).

${ }^{109}$ Hanratty v Lord Butler [1971] unreported Court of Appeal judgment.

110 Defreitas v Benny [1976] AC 234, 247 (Lord Diplock).
} 
refusal to grant a posthumous pardon. The decision was influenced by a succession of Privy Council decisions in death penalty appeals from Commonwealth Caribbean states. ${ }^{111}$ The prerogative of mercy should not now be seen, the court said, as an 'arbitrary monarchical right of grace and favour', but rather as a 'constitutional safeguard against mistakes'.112 Bentley offers a rare example of a claimant winning in a prerogative case. ${ }^{113}$ But even here there are still traces of abnormality within the judgment. At the close of the case, the court declined to make a formal order, but instead invited the Home Secretary to look at the matter again. Despite the constitutionalist rhetoric that marks the judgment, then, the case still shows some signs of reticence in the handling of the prerogative.

A wider gap between rhetoric and reality, principle and result, is more typical of prerogative cases, a gap that tends to be particularly pronounced where the power in question approaches 'forbidden zones' of high policy. In no area of public law, Adam Tomkins remarks, 'are the courts as reluctant to review government actions and decisions as when they touch upon the prerogative.'114 The $G C H Q$ case itself, the originary decision in the modern series, fits this profile. So too does Bancoult. Both cases contain a similar process of reasoning that I will call the prerogative two-step: Step one, the refusal to countenance the idea of a gap in the normal framework of the law and the assertion that ordinary legal principles apply to prerogative law-making. Step two, the accommodation of government interests ('act of state'; 'national security') and equivocation or uncertainty in the application of those principles.

This two-step will be familiar to those who are conversant with the cases. In the treaty-making context, for instance, the courts have moved away from a previous stance whereby these matters were taken to be non-justiciable ${ }^{115}$ to a more subtle position in which review is open, even invited, ${ }^{116}$ but the exercise of that review is light touch in the extreme. ${ }^{117}$ The pattern is replicated in the diplomatic context more generally, as two cases brought on behalf of Guantanamo Bay detainees illustrate. The judges in those cases dutifully intoned the post$G C H Q$ mantra that it 'is not an answer to a claim of judicial review to say that the

\footnotetext{
111 See, eg, Pratt and Morgan v A.G of Jamaica [1993] 4 All ER 769; Lewis v A.G. of Jamaica [2001] 2 AC 50. See also L.R. Helfer, 'Overlegalizing Human Rights: International Relations Theory and the Commonwealth Caribbean Backlash Against Human Rights Regimes' (2002) 102 Columbia Law Review, 1832.

112 R v Secretary of State for the Home Department, ex p Bentley [1993] EWHC Admin 2.

${ }^{113}$ See also R (Michael Shields) v Secretary of State for Justice [2008] EWHC 3102 (Admin).

114 A. Tomkins, Our Republican Constitution (Oxford: Hart Publishing, 2005), 133.

115 See, eg, Blackburn v Attorney-General [1971] 1 W.L.R. 1037 (per L Denning): 'When [HM] Ministers negotiate and sign a treaty...they act on behalf of the country as a whole. They exercise the prerogative of the Crown. Their action in so doing cannot be challenged or questioned in these courts.'

116 In R v Secretary of State for Foreign and Commonwealth Affairs, exp Lord Rees Mogg [1993] EWHC Admin 4 the applicant was given standing to challenge the ratification of the Maastricht Treaty on the (transparently weak) basis of his 'sincere concern for constitutional issues'.

117 ibid. See also Ex p Molyneaux [1986] 1 W.L.R. 331 (the text of an intergovernmental conference established by the UK and Irish governments was 'akin to a treaty' and should as such be reviewed gingerly).
} 
source of the power' is the prerogative. But they also said that 'the court cannot enter the forbidden areas, including decisions affecting foreign policy'. ${ }^{118}$ The result was the weakest of weak rights: a legitimate expectation that the Foreign Office would consider whether to take action on the detainee's behalf. That minimal obligation, needless to say, had already been discharged in both cases. ${ }^{119}$ Indeed, one is hard pressed to think of any circumstance where it might prove useful, save perhaps to assuage judicial feelings of guilt and inadequacy. ${ }^{120}$

On reading these cases, it is hard not to sympathize with Elliott and PerreauSaussine's mordant observations on the pyrrhic nature of judicial review of the prerogative. Reflecting specifically on Bancoult, which they see as 'of a piece with [earlier] path-breaking cases', the authors conclude that 'one more such victory could utterly undo those public lawyers who defend the existence of constitutional legal constraints on the use of prerogative power'. ${ }^{121}$ The implicit accusation is that the courts' approach to reviewing prerogative is now anachronistic - the courts have not fully jettisoned outdated vertical and personal conceptions of authority from which prerogative derived. To the extent that this accusation holds true, it shows how the evolutionary nature (or 'past-ness') of judicial review can serve not just to shore up established liberal positions against claims for exceptional and illiberal new powers, but can also enable old positions to resonate long after their normative relevance has declined. (This does nothing in itself to dent Elliott and Perreau-Saussine's point. As Oliver Wendell Holmes said, 'It is revolting to have no better reason for a rule of law than that it was laid down in the time of Henry IV.'122)

But I suspect that there is something more at work here, beyond straightforward anachronism. This is not to say that there are no anachronistic elements in these cases. The prerogative form, inextricably related as it is to a time when kings had power, ${ }^{123}$ can be nothing else: its operative premises simply do not match core elements of democratic constitutionalism. (But, then again, much the same could be said about other, more standard features of the British Constitution.) But perhaps it is better to understand the prerogative as a political statement, one that carries with it a certain ring derived no doubt from the personal and sacral characteristics that clung to prerogative power in times past, but which are now refracted through the notion of (populist) democracy and the need for government to be responsive to popular demands. (Recall Hamilton on the executive qualities - 'decision, activity, secrecy, and despatch'.124) More than an

\footnotetext{
118 R (Abbasi) v Secretary of State for Foreign and Commonwealth Affairs [2002] EWCA Civ 1598 at [106]. ${ }^{119}$ See also R (Al-Rawi) v Secretary of State for Foreign and Commonwealth Affairs [2006] EWCA Civ 1279.

120 The courts saw no apparent incongruity between this result and the forthright criticism in one of them of the way the US legal system was handling the detention of enemy combatants - Lord Phillips described US policy as 'objectionable' in Abbasi at [66].

121 n 55 above, 717.

122 O.W. Holmes, 'The Path of the Law' (1897) 10 Harvard Law Review, 457, 469.

$123 \mathrm{cf}$ A.V. Dicey, Introduction to the Study of the Law of the Constitution (1885, London: Macmillan, 10th ed, 1959), 424: prerogative is that 'residue of discretionary or arbitrary authority, which at any given time is legally left in the hands of the Crown.'

${ }^{124}$ J. Madison, A. Hamilton, and J. Jay, The Federalist (London: J.M. Dent, 1992), No 70, 360.
} 
echo remains of the connection between prerogative power and personal authority. Although its controversial nature means that exercising the prerogative may sound a warning to other political actors, particularly the courts, to tap into prerogative is still to tap into a source of charismatic authority. This does not, and probably could not, appear on the surface of the cases. But it does help to explain the prevalence and persistence of the two-step. The use of prerogative amounts to a 'speech act' (more precisely, an indirect illocutionary act ${ }^{125}$ ) whereby government seeks to put itself in a particular position vis-à-vis the court. This is a special domain, it asserts, where special conditions apply. Courts should be mindful to tread warily.

This pattern in cases involving the prerogative in the strict sense is worrying enough for believers in the 'rule of law project'. ${ }^{126}$ But more troubling still is the existence of a similar two-step in cases where the prerogative in its broader sense operates. In terrorism cases, for instance, ${ }^{127}$ courts have taken a hard line on government arguments asserting a right to be free from legal constraint. At the level of principle, that is, they emphasize the application of settled, standing law (step 1). But the cases also typically contain strong doses of deference in the application of those principles (step 2). The House of Lords' decision in the torture evidence case is a perfect illustration. On the question of principle, the Law Lords were emphatic: the condemnation of torture was a 'constitutional principle', reflecting both a 'deeply-rooted tradition and an international obligation solemnly and explicitly undertaken'. ${ }^{228}$ But when it came to matters of detail, their approach was more conciliatory. ${ }^{129}$ The test to be applied, they said, was for evidence to be excluded where on the balance of probabilities it had been obtained by torture. This meant not only that evidence should be let in if there was doubt about its provenance, but also that the terrorist suspect would be in the invidious position of needing to raise a plausible case that evidence, about which he might know little or nothing and that would probably have been obtained through half-secret intelligence back-channels, had been obtained through torture. Subsequent cases, while less dramatic, have followed a broadly similar path. ${ }^{130}$ Even the applicants' victory in the Belmarsh case, ${ }^{131}$ which largely bucks the trend, ${ }^{132}$ looks less

\footnotetext{
125 J. Searle, 'A Taxonomy of Illocutionary Acts' in K. Günderson (ed), Language, Mind, and Knowledge, Vol. 7 (Minneapolis: University of Minnesota Press, 1975).

126 See, eg, Dyzenhaus, n 21 above.

127 See also, eg, R (McCann) v Manchester Crown Court [2003] 1 A.C. 787. For analysis see, eg, P. Ramsay, 'What is Anti-Social Behaviour?' (2004) Criminal Law Review, 908.

128 A v Secretary of State for the Home Department [2005] UKHL 71 at [12], [51] (Lord Bingham).

$129 \mathrm{ibid}$ at [100], [119] (Lord Hope): 'it would be unrealistic to expect SIAC to demand that each piece of information be traced back to its ultimate source... Too often we have seen how the lives of innocent victims and their families are torn apart by terrorist outrages. Our revulsion against torture...must not be allowed to create an insuperable barrier for those who are doing their honest best to protect us. A balance must be struck between what we would like to achieve and what can actually be achieved in the real world.'

${ }^{130}$ See, eg, Secretary of State for the Home Department v Rehman [2001] UKHL 47; Abu Qatada v Secretary of State for the Home Department [2007] UKSIAC 15/2005; R (Corner House Research) v The Serious Frand Office [2008] UKHL 60.

131 n 23 above.
} 
convincing in light of subsequent events. For one thing, the practice of internment criticized in the case was replaced by a system of control orders that was in most ways little better and in some ways worse than what preceded it. The courts have found it hard to deal with this new system of exceptional control, partly no doubt because they feel complicit in its genesis. ${ }^{133}$ For another, Belmarsh led to a backlash against the court and persistent threats to amend or repeal the Human Rights Act and curb the court's powers of review. ${ }^{134}$

In recognizing, albeit obliquely, the continued importance of personal and charismatic modes of authority, the prerogative cases reveal a fissure in modern conceptions of constitutional rule. For the sacral element did not disappear with the removal of kings from the political landscape; rather, it was transmogrified. Paul Kahn, in a disquisition on sovereignty and violence, refers to this 'changing locus of the sacred', and remarks that the 'popular sovereign remains as mystical and sacred an entity as the king ever was. ${ }^{135}$ Sovereignty and charismatic or personal authority, once residing (somehow) in the body of the King, have separated, the former resting with 'the people', the latter embodied in the figure of a government or Leader, in whom we are asked to place our faith, our trust. Vertical relations are supposedly anathema within a structure of political equals. There are no servants now; and neither are there masters. The gap that previously existed between the law and those subject to it closes. Living in a horizontal political universe means that there is in principle no separation between the citizen and the acts of government, for they are now our acts - or at least acts done in our name. 'The sovereign god is no longer at a distance; mediation is no longer necessary. ${ }^{.136}$

But this horizontal structure, familiar though it is, carries with it certain dangers. It is an often remarked upon paradox that the older, vertical structures of rule, with their conditioning ideology of service, allegiance, and (political) love, often tended to be less oppressive than the more egalitarian systems that replaced them. As the powers of noblemen and princes waned, the new type of power that emerged turned out to be 'more centralized, more enterprising, more absolute, more extensive' than those it replaced. ${ }^{137}$ Modern political systems seem almost structurally inclined towards the aggregation of power. 'Contemporary societies are tempted by unlimited power, much more than was true, in the premodern age, even of the king most jealous of his absolute sovereignty. ${ }^{138}$

This situation is particularly problematic in a world inhabited by Tocquevillian individualists. To see why, we can turn to Hobbes's acute

\footnotetext{
132 The deferential element in this case relates (Lord Hoffmann's judgment aside) to the way the court handled the sovereign question of whether a state of emergency can be said to exist.

133 Secretary of State for the Home Department v JJ [2007] UKHL 45; Secretary of State for the Home Department $\mathrm{v}$ MB [2007] UKHL 46; Secretary of State for the Home Department v E [2007] UKHL 47.

${ }^{134}$ See, eg, 'David Cameron: Scrap the Human Rights Act' (22 August 2007) Daily Telegraph.

135 P.W. Kahn, Sacred Violence: Torture, Terror, and Sovereignty (Ann Arbor: University of Michigan Press, 2008), 34.

136 ibid, 37.

137 Tocqueville, $\mathrm{n} 12$ above, 659 .

138 Brague, n 94 above, 263.
} 
identification of the interplay of love and hatred that attends indebtedness. Political debts are also personal, particularly in a political world characterized by consumerism. Hobbes argued that to receive benefits from an acknowledged superior inclines one to love. Likewise, to receive benefits from an equal where 'there is hope of requital' also 'disposeth to love'. (Indeed, the relationship between equals where there exists an equal obligation of 'aid and service mutual' is the best of all possible worlds 'wherein the victor is pleased with his victory, and the other revenged by confessing it.' It might also be said to equate to the ideal structure of republican citizenship.) In stark contrast, however, we develop a 'secret hatred' towards an equal from whom we receive 'greater benefits than there is hope to requite.' ${ }^{139}$ Acts of love turn into conditions of hatred in relationships of equality because, by incurring debts that can never repaid, they create a psychology of perpetual service with which love between equals is incompatible. ${ }^{140}$

If Hobbes is right, then it may be that 'late' democratic systems exist in an unstable equilibrium. The argument from Hobbes is as follows: Tocquevillian individuals function as political consumerists, demanding action from government. Government responds to those demands (following the logic of modern democratic rule) by passing new laws and accruing more powers. But consumerist appetite is insatiable. Government action simply drives calls for more action. The government's action can no longer be seen as a gift from one equal to another, of the sort that can turn the polity towards self-love (which corresponds to the ideal of republican citizenship). For one thing, the consumerist understands himself as having no reciprocal duty to government that might generate such a sentiment. For another, the government has become too powerful to be considered a political equal. The consumerist logic is more likely to generate feelings of self-hatred and mutual distrust - which in turn drives demands for more government action. The result: Tocqueville's nightmare. In such conditions, more power equals more separation between people and government equals more self-hatred and fear. ${ }^{141}$

This is not meant to be a counsel of despair. There is nothing inevitable about the consumerist-driven downward spiral. The paradigm of consumerist politics exists alongside and competes with other conceptions of the relationship between government and governed - republican citizenship, for instance. Perhaps the grand narrative for judicial review in the future can be constructed in these terms. We might understand the function of judicial review, forever tugging on Superman's cape, ${ }^{142}$ as a contribution to shoring up a republican conception of politics as one of equals equally bound. Certainly, political disputes are more likely than ever to be played out at least partly in a legal register and argued before courts. As this study of law and the prerogative shows, the courts have done much

139 T. Hobbes, Leviathan, The First Part, Chapter 11 'Of the Difference of Manners'.

140 See Schalkwyk, n 87 above, 182.

${ }^{141}$ For a parallel analysis, see A. Somek, Individualism: an Essay on the Authority of the European Union (Oxford: Oxford University Press, 2008).

${ }^{142}$ M. Taggart, 'Tugging on Superman's Cape: Lessons from Experience with the New Zealand Bill of Rights Act 1990' (1998) Public Law, 266. 
to fashion judicial review so that it becomes possible to bring previously halfimmune exercises of power within the domain of 'ordinary' law. However, greater attention needs to be paid not just to the gaps that continue to operate in the application of the ordinary law to the prerogative strictly so called, but also and more generally to the relationship between that law and the 'resurgent prerogative' that now plays out in the context of the politics of security and fear. 